\title{
Current Trends in
}

\section{Entomology and Zoological Studies}

\section{Otobius megnini (Duges, 1844) Otoacariasis in a Horse from Tlahualilo, Durango, Mexico: A Case Report}

Vicente Homero Gonzalez-Alvarez ${ }^{1}$, Josue Manuel de la Cruz-Ramos ${ }^{1}$, Sergio Orlando Yong-Wong ${ }^{1}$, Quetzaly Karmy SillerRodriguez ${ }^{2}$, Javier A. Garza-Hernandez ${ }^{3}$, Aldo Ivan Ortega-Morales ${ }^{4 *}$

'Universidad Autónoma Agraria Antonio Narro, Posgrado en Ciencias en Producción Agropecuaria, Periférico Raúl López Sánchez s/n, Col. Valle Verde, C.P. 27059, Torreón, Coahuila, México

${ }^{2}$ Universidad Juarez del Estado de Durango, Facultad de Ciencias de la Salud, Calzada Las Palmas 1 y Sixto Ugalde, Col. Revolucion, C.P. 35050, Gomez Palacio, Durango, México

${ }^{3}$ Universidad Autonoma de Ciudad Juarez, Instituto de Ciencias Biomedicas, Laboratorio de Entomologia Medica, Anillo Envolvente y Estocolmo s/n, Zona Pronaf, C.P. 32310, Cd. Juarez, Chihuahua, Mexico.

${ }^{4}$ Universidad Autónoma Agraria Antonio Narro, Departmento de Parasitologia Periférico Raul Lopez Sanchez s/n, Col. Valle Verde, C.P. 27059, Torreon, Coahuila, México

"Corresponding author: Aldo Ivan Ortega-Morales, Departmento de Parasitologia, Universidad Autonoma Agraria Antonio Narro, Periferico Raul Lopez Sanchez s/n, Col. Valle Verde, C.P. 27059, Torreon, Coahuila, Mexico. Email: agrortega@hotmail.com

Citation: Gonzalez-Alvarez VH, de la Cruz-Ramos JM, Yong-Wong SO, Siller-Rodriguez QK, Garza-Hernandez JA, et al. (2018) Otobius megnini (Duges, 1844) Otoacariasis in a Horse from Tlahualilo, Durango, Mexico: A Case Report. Curr Trends Entomol Zool Stds: CTEZS-108. DOI: 10.29011/ CTEZS-108. 000008

Received Date: 17 April, 2018; Accepted Date: 11 June, 2018; Published Date: 20 June, 2018

\section{Abstract}

This study reports the infestation of a horse by the tick Otobius megnini. A total of 82 specimens were collected from both ears during a routine consultation, and by morphological examination, all the specimens corresponded with the description of the ear tick. Studies are necessaries to determine the life cycle, the range of hosts, and the role in the transmission of diseases of public and veterinary concern by this tick in our region.

Keywords: Argasidae; Ear tick; Horse; Otitis; Public health

\section{Introduction}

Otoacariasis is defined as the affection of the ear canal, in which the causal agent is an arthropod classified in the subclass Acari [1]. Such as mites of the Democidae, Psoroptidae Sarcoptidae families or ticks grouped as Argasidae or Ixodidae [2]. Mites reported as a cause of mange in horses are Chorioptes equi, Psoroptes-equi and Sarcoptes scabiei var equi [3]. While the ticks commonly found in horses belong to the genera Amblyomma spp., Dermacentor spp., Ixodes spp., Rhipicephalus (Boophilus) spp. and Otobius megnini [4]. O. megnini as is a one host life cycle, in which the immature stages feed on blood inside the ear canal. As larva, it feeds for one to two weeks, while as nymph it feeds for one to seven months. When replete, nymphs drop off the host and crawl in to cracks of trees or buildings, where they melt into adults, mate, and lay eggs [5]. While the tick is in its parasitic stage, inside the ear canal, it causes pain which develops a variety of clinical signs, including head shaking, colic, emaciation, hyperesthesia, tremors and muscle spasms, and paralysis. Moreover, mechanical damage caused with its mouth parts provokes inflammation of the ear canal, tympanic membrane, and cause otitis interna, likewise secondary microbial infections of wounds could be developed [6]. Around the world, the presence of $O$. megnini in horses has been described in Argentina [7], Bolivia [8], Chile [9], and Sri Lanka [10]. While in Mexico. The first report of this soft tick comes from 1884 [11, Table1]. Notwithstanding, reports of this tick parasitizing horses in our country represents a gap in knowledge therefore, this study describes a case of otitis caused by the ear tick in a horse from Tlahualilo, Durango, Mexico. 


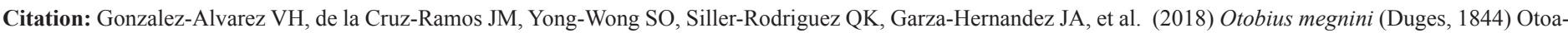
cariasis in a Horse from Tlahualilo, Durango, Mexico: A Case Report. Curr Trends Entomol Zool Stds: CTEZS-108. DOI: 10.29011/ CTEZS-108. 000008

\begin{tabular}{|c|c|c|}
\hline Locality & Climate* & Host(s) \\
\hline Aguascalientes & Dry & \multirow{9}{*}{$\begin{array}{c}\text { Humans: Homo sapiens } \\
\text { Cats: Felis catus } \\
\text { Cattle: Bos spp. } \\
\text { Cervidae: Odocoileus spp. }\end{array}$} \\
\hline Baja California & Dry semi-arid & \\
\hline Chihuahua & Dry semi-arid & \\
\hline Coahuila & Dry semi-arid & \\
\hline Colima & Warm sub-humid & \\
\hline Durango & Semi-arid, tempered sub-humid & \\
\hline Guanajuato & Tempered sub-humid & \\
\hline Guerrero & Warm sub-humid & \\
\hline Hidalgo & Semi-arid, tempered sub-humid & \\
\hline Jalisco & Semi-arid, warm sub-humid & \multirow{10}{*}{$\begin{array}{c}\text { Dogs: Canis lupus familiars } \\
\text { Donkeys: Equus asinus }\end{array}$} \\
\hline Estado de México & Tempered sub-humid, warm sub-humid & \\
\hline Michoacán & Warm sub-humid tempered sub-humid & \\
\hline Morelos & Warm sub-humid tempered sub-humid & \\
\hline Oaxaca & Warm sub-humid, warm humid & \\
\hline Puebla & Tempered sub-humid, warm sub-humid & \\
\hline Sinaloa & Warm sub-humid, dry semi-arid & \\
\hline Sonora & Dry semi-arid & \\
\hline Tlaxcala & Tempered sub-humid & \\
\hline Distrito Federal & Tempered sub-humid & \\
\hline
\end{tabular}

Table 1: Characteristics on the distribution of O. megnini in México, adapted from Hoffman [11].

\section{Case Report}

On October 25/2017, a 10-year-old male horse was referred for consultation. The patient works in range land, co-existing with livestock and during the night is housed outdoors. The main signs found were restlessness and head shaking. At the examination of the ear canal, several foreign bodies were visually detected. As possible, all the material was manually extracted and deposited in a tray. Ear wax and debris were inspected carefully, and several arachnid-like arthropods were separated from the sample. The arthropods were deposited in appropriately labeled vials and transported to the Department of Parasitology of the Universidad Autonoma Agraria Antonio Narro for identification purpose. All the specimens were washed and under stereoscopic microscopy identified by adequate taxonomic keys [12].

\section{Results and Discussion}

All the collected specimens corresponded with the description of the ear tick $O$. megnini [12]. A total of 82 specimens were collected (Table 2) and classified by life stage as described by Diyes and Rajakaruna [13], characteristics of the tick are described in Figure 1.

\begin{tabular}{|c|c|c|c|c|c|}
\hline Instar & \multicolumn{2}{|c|}{ Larvae } & \multicolumn{3}{c|}{ Nymphs } \\
\hline Condition & Unfed & Engorded & Unfed & $\begin{array}{c}\text { Semi } \\
\text { engorded }\end{array}$ & Engorded \\
\hline
\end{tabular}

\begin{tabular}{|l|l|l|l|l|l|}
\hline Total & 7 & 56 & 5 & 4 & 10 \\
\hline
\end{tabular}

Table 2: Categorization of the specimens recovered.

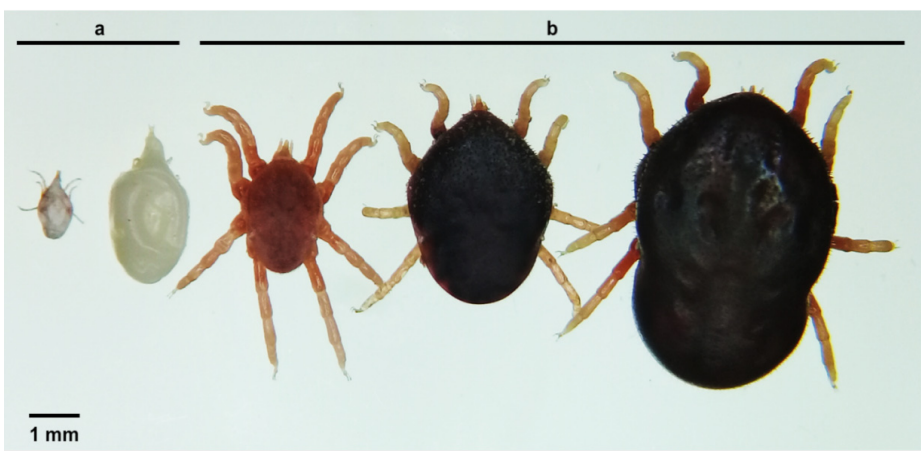

Figure 1: Dorsal view of O. megnini specimens, a: unfed and engorged larvae; b: unfed, semi-engorged and engorged nymphs. The texture of integument with the characteristic spines can be observed.

Treatment was initiated by removing ear wax and debris by mechanical cleaning of the ear. Chlorhexidine gluconate diluted in water was used as a final step of the ear cleaning, to prevent pathogen colonization. An acaricide in a petroleum jelly base was prescribed in order to control reinfestation of ticks. Furthermore, as $O$. megnini prefers cracks and crevices to hide and lay eggs, fumigation of the resting place was recommended. Madigan et al. [14] and Zarate-Ramos et al. [15] reported that 


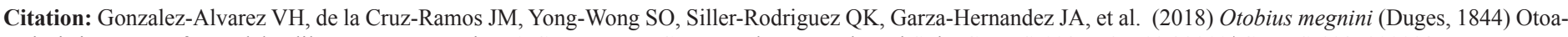
cariasis in a Horse from Tlahualilo, Durango, Mexico: A Case Report. Curr Trends Entomol Zool Stds: CTEZS-108. DOI: 10.29011/ CTEZS-108. 000008

this tick was associated with clinical manifestations including colic, hyperesthesia, hyper tonicity, muscle spasms, prolapse of the third eyelid, and tremors; however, otitis was not stated. Furthermore, in both cases, the horses recovered of clinical signs until they received treatment for the ear ticks. In this report, the patient did not manifest colic evidence, only head shaking, another clinical manifestation described by Madigan et al. [14]. The ear tick is commonly reported as a parasite of horses [7-10]. Severe infestations with $O$. megnini could block the ear canal and cause injuries with secondary bacterial infections, and nervous affection, causing balance dysfunctions commonly confused with neuromuscular disorders of another origin [16].

\section{Conclusion}

Due to the putative role of $O$. megnini in the transmission of Coxiella burnetii, the Q fever agent [12] studies are necessaries to determine the life cycle, the range of hosts, and the role in the transmission of diseases of public and veterinary concern by this tick in our region.

\section{Acknowledgment}

The authors thank the support of the Mexican National Council of Science and Technology (CONACYT) for the scholarship awarded for postgraduate studies.

\section{References}

1. Abi-Akl P, Haddad G, Zaytoun G (2017) Otoacariasis: an infestation of mites in the ear. Ann Clin Case Rep 2: 1329.

2. Urquhart GM, Armour J, Duncan JL, Dunn AM, Jennings FW (1996) Veterinary Parasitology. $2^{\text {nd }}$ Edition. Black well Science, Cambridge, Mass.

3. Kotb S, Abdel-Rady A (2013) Epidemiological studies of equine mange with special reference to different therapeutic protocols for effective treatment of Chorioptic mange. Ass Univ Bull Environ Res 16: 29-52.

4. Duell JR, Carmichael R, Herrin BH, Holbrook TC, Talley J, Little SE (2013) Prevalence and species of ticks on horses in central Oklahoma. J Med Entomol 50: 1330-1333.
5. Walker AR, Bouattour A, Camicas JL, Estrada-Peña A, Horak IG, et al. (2003) Ticks of domestic animals in Africa: a guide to identification of species. Bioscience Reports Edinburgh Scotland, U.K.

6. Skvarla MJ, Evans GE, Fisher JR, Dowling APG (2015) Clinical report of the spinose ear tick, Otobius megnini (Acari: Parasitiformes: Argasidae), from a domestic cat, Felis silvestris catus, and first record from Northwest Arkansas. Midsouth Entomologist 8: 64-72.

7. Guglielmone AA, Mangold AJ (1986) La distribución geográfica de Otobius megnini (Dugés, 1884) (Acarina: Ixodoidea: Argasidae) en la Argentina. Veterinaria Argentina 3: 582-587.

8. Mastropaolo M, Beltrán-Saavedra LF, Guglielmone AA (2014) The ticks (Acari: Ixodida: Argasidae, Ixodidae) of Bolivia. Ticks Tick Borne Dis 5: 186-194.

9. González-Acuña D, Guglielmone AA (2005) Ticks (Acari: Ixodoidea: Argasidae, Ixodidae) of Chile. Exp Appl Acarol 35: 147-163.

10. Diyes GCP, Akalanka PM, Rajakaruna RS (2014) Lifecycle of spinose ear tick Otobius megnini associated with horse otoacariasis in Sri Lanka. Proceedings of the Peradeniya Univ. International Research Sessions, Sri Lanka. Vol. $18,4^{\text {th }} \& 5^{\text {th }}$ July. p. 484.

11. Hoffmann A (1962) Monografía de los Ixodoidea de México: parte I. Rev Soc Mex Hist Nat 23: 191-307.

12. USDA (1976) Ticks of Veterinary Importance. Handbook of Agriculture USA. Pg No. 485

13. Diyes GCP, Rajakaruna RS (2017) Lifecycle of spinose ear tick, Otobius megnini (Acari: Argasidae) infesting the race horses in Nuwara Eliya. Sri Lanka Acta Trop 166: 164-176.

14. Madigan JE, Valberg SJ, Ragle C, Moody JL (1995) Muscle spasms associated with ear tick (Otobius megnini) infestations in five horses. J Am Vet Med Assoc 207: 74-76.

15. Zarate-Ramos JJ, Nevarez Garza AM, Zamora-Avila DE, RodriguezTovar LE (2014) Myotonia and colic associated with the spinose ear tick, Otobius megnini, in a horse in Northern Mexico. Res J Parasitol 9: $1-5$.

16. Mans BJ, Gothe R, Neitz AW (2004) Biochemical perspectives on paralysis and other forms of toxicoses caused by ticks. Parasitology 129: S95-111. 